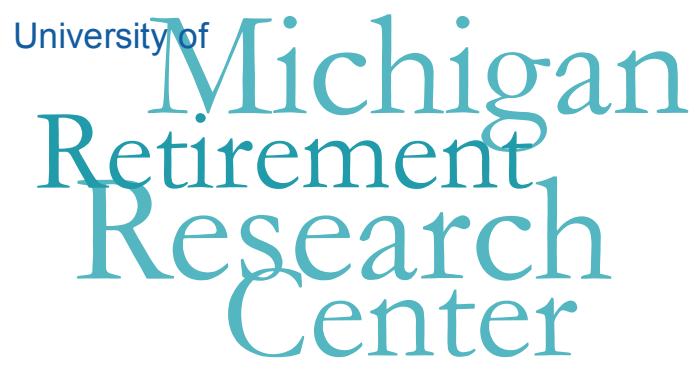

Working Paper

WP 2010-244

\title{
Protecting the Household Incomes of Older Workers with Significant Health-Related Work Limitations in an Era of Fiscal Responsibility
}

Jody Schimmel and David C. Stapleton

\begin{tabular}{|l|l|}
\hline $\mathrm{M}$ & $\mathrm{R}$ \\
\hline $\mathrm{R}$ & $\mathrm{C}$ \\
\hline
\end{tabular}

Project \#: UM10-03 


\title{
Protecting the Household Incomes of Older Workers with Significant Health-Related Work Limitations in an Era of Fiscal Responsibility
}

\author{
Jody Schimmel \\ Mathematica \\ David C. Stapleton \\ Mathematica \\ December 2010 \\ Michigan Retirement Research Center \\ University of Michigan \\ P.O. Box 1248 \\ Ann Arbor, MI 48104 \\ http://www.mrrc.isr.umich.edu/ \\ (734) 615-0422
}

\section{Acknowledgements}

This work was supported by a grant from the Social Security Administration through the Michigan Retirement Research Center (Grant \# 10-M-98362-5-01). The findings and conclusions expressed are solely those of the author and do not represent the views of the Social Security Administration, any agency of the Federal government, or the Michigan Retirement Research Center.

Regents of the University of Michigan

Julia Donovan Darrow, Ann Arbor; Laurence B. Deitch, Bingham Farms; Denise Ilitch, Bingham Farms; Olivia P. Maynard, Goodrich; Andrea Fischer Newman, Ann Arbor; Andrew C. Richner, Grosse Pointe Park; S. Martin Taylor, Gross Pointe Farms; Katherine E. White, Ann Arbor; Mary Sue Coleman, ex officio 


\title{
Protecting the Household Incomes of Older Workers with Significant Health-Related Work Limitations in an Era of Fiscal Responsibility
}

\begin{abstract}
Many proposals designed to reduce federal budget deficits include retirement policy reforms that would delay workers' access to retirement benefits or reduce the value of benefits to those who retire early. Such reforms would have adverse consequences for the economic well-being of older workers with health-related work limitations. In this paper, we explore a set of policy options that take a "work-support" approach-an earned income tax credit (EITC), an employment services allowance, and a health insurance subsidydesigned to encourage and help workers continue to work if they can.
\end{abstract}

To arrive at a population that might be eligible for such benefits, we first develop a straightforward model to predict the likelihood that a worker reporting a health-related work limitation would experience economic hardship as a result. The model bounds the target population by excluding those who are not expected to experience financial hardship from earnings loss due to a health-related work limitation. It also demonstrates an approach to eligibility determination that would discourage gaming and support rapid eligibility determination-critical for a program designed to extend employment and prevent financial hardship.

Using conservative assumptions about program costs, our most expensive program would have a per capita cost of $\$ 14,600$, or $\$ 11,300$ if the health insurance subsidy is viewed as an ACA cost. This can be compared to estimated mean annual benefits of $\$ 14,855$ in 2009 for Social Security Disability Insurance (SSDI) beneficiaries age 50 and older, plus $\$ 11,000$ per year for Medicare after the 24-month waiting period. Because of its more favorable work incentives, a work-support program is likely to reduce hardship more than a program that preserves existing benefits for the same workers at comparable cost and is likely to be no more difficult to administer. 


\section{INTRODUCTION}

Many policy proposals designed to reduce future deficits in the federal budget include retirement policy reforms that would delay workers' access to retirement benefits or reduce the value of benefits to those who retire early. For example, the final report of the National Commission of Fiscal Responsibility and Reform (NCFRR), endorsed by 11 of its 18 members, has called for indexing the full retirement age (FRA) and the earliest eligibility age (EEA) for Social Security Retirement (SSR) benefits (NCFRR 2010), while a proposal from the Bipartisan Policy Center (2010) maintains those ages but indexes benefit levels to life expectancy.

It is widely acknowledged, however, that such reforms would have adverse consequences for the economic well-being of older workers with health-related work limitations. In previous work, we found that average earnings for those who first reported a work limitation between age 53 and 64 were approximately 48 percent lower $(\$ 16,000$ in 2008 dollars) two years after onset than for a comparison sample who did not experience a new work limitation (Schimmel and Stapleton 2010). We also found the likelihood of being in poverty is nearly twice as high after onset among those with work limitations as it is for an otherwise similar group without such limitations. These findings are consistent with a large body of research demonstrating that the households of a substantial number of older workers experience economic hardship after the onset of health-related work limitations (Coile 2004; Coile and Milligan 2006; Johnson et al. 2006; Johnson et al. 2007; Johnson and Mermin 2008; Schimmel and Stapleton 2010; Stapleton et al. 2008).

Some retirement reform proposals address the circumstances of older workers with healthrelated work limitations through provisions that would preserve their existing benefits or make it easier for them to attain Social Security Disability Insurance (SSDI) benefits. In contrast, in this

paper we explore a set of policy options that take a "work-support" approach—options designed to encourage and help workers continue to work if they can, perhaps with reduced hours or at lower- 
paying jobs. We leave open the option of SSDI benefits for those who cannot earn more than a minimal amount.

The work-support approach has several distinct merits relative to the benefit preservation approach. First, it is likely to maintain, or even improve, the household incomes of those with health-related work limitations at lower cost than the benefit preservation approach because such workers will continue to rely on their own earnings as a substantial income source. Second, it is consistent with the objective of retirement policy reform encouraging later retirement. Third, it is also consistent with the direction of current disability policy reform, moving in the direction of assistance for work rather than payment of benefits to those who do not work.

We consider three specific work-support options for eligible workers:

- An expanded earned income tax credit (EITC), comparable to the credit currently available to parents with three children

- An employment support allowance (ESA) — a payment to eligible workers provided that they do not apply for SSDI benefits

- A health insurance subsidy, designed to be comparable to that specified in the Affordable Care Act (ACA) for those who purchase insurance through a health insurance exchange - an option that will presumably become available to all persons without employer coverage as health care reform is implemented

The specification of these options as well as our analysis of them is exploratory in nature; our primary intent is to stimulate interest in work-support options as a practical alternative to benefit preservation options for targeted workers. A secondary intent is to show that options such as these can be both practical, in terms of the number of eligible workers and gross programmatic costs, and effective at reducing economic hardship.

To arrive at a population that might be eligible for such benefits, we first develop a straightforward model to predict the likelihood that a worker reporting a health-related work limitation would experience economic hardship as a result. The model serves to bound the target population, excluding those who are not expected to experience financial hardship from an earnings 
loss due to a health-related work limitation. It also provides a framework that could be used to support rapid eligibility determinations. Given that the ultimate goal is to keep individuals in the labor force, a rapid determination process is of utmost importance. An actual program could follow the same approach but would have access to much richer information than can be found in a survey.

The demands of the analysis and the limitations of the data required that we make assumptions that are substantially arbitrary. Nonetheless, we are able to address four questions about our proposed work-support options:

- How many workers would be eligible under a program that targets those most likely to experience economic hardship as they approach retirement?

- How high would per-capita costs be, how would costs vary with the generosity of the options and the eligibility criteria, and how would they compare to the per capita costs of benefit preservation alternatives?

- How large would the gross programmatic costs of the options be, and how would costs vary with the generosity of the options and the eligibility criteria?

- To what extent would the options reduce economic hardship among those who experience health-related work limitations as they approach retirement?

Under the specification and assumptions that lead to the most expensive program considered, per capita cost is about $\$ 14,600$ annually. Of this amount, approximately $\$ 1,500$ is for the EITC, $\$ 8,500$ for the ESA, and $\$ 3,000$ for the health insurance subsidy. These estimates are upper bounds of the likely costs because they are based on the most expansive definition of eligibility considered and because we use conservative assumptions about program take-up (100 percent) and the cost of the ESA (the highest amount that SSA will pay for services provided to SSDI beneficiaries under the Ticket to Work program). Further, if the provisions of the ACA are implemented as enacted, the health insurance subsidy should not be considered a new cost. Per capita annual cost for other plausible options is as low as $\$ 3,200$.

By comparison, mean annual SSDI benefits for beneficiaries age 50 and older were $\$ 14,855$ in 2009 (Social Security Administration 2010). Hence, our expectation is that a work-support option, 
on average, would cost less per capita than SSDI benefits, especially if the ACA health insurance subsidy is already in place. The relative cost of these options is even lower once the cost of Medicare for SSDI beneficiaries is factored in. SSDI beneficiaries become eligible for Medicare after 24 months on the SSDI rolls, at an annual per capita cost of approximately $\$ 11,000$ in 2009 (Dahl and Meyerson 2010).

The analysis also demonstrates that these options would substantially reduce poverty among the families of qualified workers-by 80 percent under the most costly option. Other less costly options yield appreciable, although smaller, declines in poverty rates. Because of its more favorable work incentives, a work-support program is likely to reduce hardship more than would a program that preserves existing benefits for the same workers at comparable cost.

The paper proceeds as follows. In Section II, we describe the data from the Health and Retirement Study (HRS) that we used to support the analysis. Section III lays out a range of criteria for program eligibility and discusses the size of the eligible population under a variety of assumptions. Section IV specifies the policies we model to achieve the goals of reducing hardship while encouraging work. In Section V, we provide estimates of program costs under a range of plausible scenarios for both the size of the eligible population and the generosity of the benefits. Section VI concludes with a discussion of implications of our findings for policy, including a discussion of how obstacles to the administration of such a program might be overcome. 


\section{DATA DESCRIPTION AND SAMPLE SELECTION}

The HRS is a longitudinal survey of U.S. adults over age 50 that began in 1992. Follow-up interviews have been attempted for all respondents to the original wave in every other year from 1994 to 2008 , unless the respondent had died, with a high rate of success. ${ }^{1}$ The HRS contains a large battery of questions that are useful for our analysis, including detailed demographic information, multiple components of household income (including earnings and receipt of federal disability insurance and retirement benefits for each adult in the household), and self-reports of medical conditions that limit the respondent's ability to work.

Our analysis focuses on a two-year age cohort from the original HRS sample- those who were born in 1940 and 1941 and were age 51 and 52 when the first survey was conducted. ${ }^{2}$ In 1992, this sample represented approximately 4.81 million individuals; attrition due to mortality reduced the population size by 11.6 percent, to about 4.25 million by $2004 .{ }^{3}$ We use the biennial data for this sample through 2004, at which point individuals were age 63 or 64 . By following a two-year cohort every two years, we are able to construct a population profile of individuals in each two-year age group from 51-52 to $63-64 .{ }^{4}$ We use this information later to estimate the likely effects of policies on those age 51 to 64 in 2010.

We use self-reports on the presence of a health condition that limits one's ability to work as a proxy for disability status. Others have shown that this measure is a strong proxy for other measures

\footnotetext{
${ }^{1}$ Response rates to the survey in each wave tend to be about 85 percent. Survey documentation is available at http://hrsonline.isr.umich.edu/sitedocs/sampleresponse.pdf (accessed December 15, 2010).

2 Because of the timing of interviews relative to birthdays, some members in this cohort were 50 when first interviewed, but we approximate ages throughout the report using interview year (1992, 1994, etc.) minus birth year, ignoring small issues of timing.

3 In all of our analyses, we used wave-specific individual sampling weights provided by the HRS. Additional information about HRS sampling weights is available at http://hrsonline.isr.umich.edu/sitedocs/wghtdoc.pdf.

${ }^{4}$ All results use HRS sampling weights. Numbers presented are rounded to the nearest thousand or million, as described in each table.
} 
of disability and an unbiased predictor of the outcomes of SSDI and SSI disability determinations (Bound 1991; Benitez-Silva et al. 2004). On the other hand, this measure may be subject to justification bias, whereby respondents report such limitations to justify a recent job loss or reduction in earnings, even though the true reason is unrelated. We are unable to gauge the magnitude of justification bias; in what follows we assume that the report of a health-related work limitation is a true measure of disability status.

Reports of a health-related work limitation were high when this cohort was first interviewed and continued to rise in each subsequent interview wave (Table II.1). At the baseline interview, 16.9 percent of respondents reported having a work limitation, rising by 50 percent to 27.0 percent by $2004 .^{5}$ The latter figure is likely much lower than the percentage who experienced health-related work limitation at any point during the 12-year period because some such conditions are short term and because 11.6 percent of the cohort had died; either case could result in an underreporting of work limitations given the biennial nature of the survey.

About one-quarter to one-third of those who reported a health-related work limitation in each wave indicated that they were receiving SSDI or SSI benefits. For example, in 1992, 12.5 percent of the cohort had a limitation but was not receiving SSDI or SSI, implying that 4.4 percent of the cohort said they had a limitation and were receiving disability benefits. The relatively low rate of SSDI and SSI receipt among those reporting a health-related work-limitation could be due to a variety of factors, including a health condition not severe enough to qualify the individual for

\footnotetext{
${ }^{5}$ In each wave, respondents were asked whether they had a health condition that limited their ability to work. With the exception of 2004, this information was collected without regard to responses in earlier waves. In 2004, those who had been interviewed in 2002 and responded that they had a limitation were not asked the question. In the RAND version of the HRS used for this study, these respondents were assumed to still have a limitation in 2004 (http://hrsonline.isr.umich.edu/modules/meta/rand/index.html). Using this assumed response produced rates of reported limitation that were significantly higher than expected based on growth rates in earlier years. Hence, we imputed rates of reporting in 2004 by multiplying the number of reported cases of work limitation in 2002 by the average wave-to-wave growth rates from 1992 to 2002.
} 
disability benefits, a work history not sufficient to qualify for SSDI, or a pending application for benefits.

Table II.1. Prevalence of Health- Related Work Limitations Among Individuals Born 1940-1941, HRS 1992- 2004 Waves

\begin{tabular}{lcccc}
\hline Interview wave (ages) & Sample Size & $\begin{array}{c}\text { Population Size } \\
\text { (thousands) }\end{array}$ & $\begin{array}{c}\text { Percent with } \\
\text { Work Limitation }\end{array}$ & $\begin{array}{c}\text { Percent with Limitation } \\
\text { but Without SSDI/ SSI }\end{array}$ \\
\hline $1992(51-52)$ & 1,902 & 4,807 & 16.9 & 12.5 \\
$1994(53-54)$ & 1,738 & 4,763 & 20.0 & 15.5 \\
$1996(55-56)$ & 1,642 & 4,698 & 23.9 & 16.8 \\
$1998(57-58)$ & 1,572 & 4,314 & 23.5 & 16.1 \\
$2000(59-60)$ & 1,496 & 4,295 & 25.4 & 17.3 \\
$2002(61-62)$ & 1,463 & 4,318 & 25.0 & 17.1 \\
$2004(63-64)$ & 1,405 & 4,250 & 27.0 & 18.5 \\
\hline
\end{tabular}

Source: $\quad$ Authors' calculations based on the HRS.

Note: The sample includes individuals born in 1940-1941. The population sizes shown use the wave-specific sampling weights for the respondents in the cohort. Prevalence of healthrelated work limitation for 2004 is imputed because of an error in the HRS survey skip logic in that year.

In designing our policy options, we limited potential eligibility to those who reported a healthrelated work limitation but did not report receipt of SSDI or SSI during the same time period, in part because the options are designed to support continuation of substantial work, and in part to control costs. Our expectation is that some workers who under current law would enter SSDI, and possibly SSI, would not do so if the options proposed were available. As will be seen, this would likely produce savings to the federal government. 
Page is intentionally left blank to allow for double side copying 


\section{SPECIFYING PROGRAM ELIGIBILITY}

In this section, we describe the method we used to determine program eligibility. We identified a potentially eligible population using characteristics of HRS respondents and a predictive model simulating program eligibility requirements. Rather than assuming all workers above a specified age limit with a health-related work limitation and not receiving SSDI or SSI benefits would be allowed to participate, this model determines eligibility on the basis of an estimate of the likelihood that, in the absence of the program, the worker's household would experience financial hardship because of an earnings decline associated with the worker's health-related work limitation.

The model also illustrates a broader point that is likely key to implementation of a successful policy—namely, that readily available nonmedical information about a worker could be used to expedite eligibility determinations. To be sure, some evidence of a health condition that limits work would be required, but the data needed are not nearly as extensive as those required for SSDI. Rapid determination of eligibility is important to prevent exit from the labor force and to ensure that the worker's family does not experience the financial hardship that the program is intended to reduce.

As indicated in the introduction, this analysis is exploratory in nature and necessarily makes assumptions—at times arbitrary—about program eligibility, among other things. The eligibility assumptions critically affect the size and cost of any benefits provided. These assumptions include specification of the minimum eligibility age, the duration of eligibility, the definition of hardship, and the variables used to predict the likelihood of hardship because of earnings loss associated with a health-related work limitation. Each of these criteria ultimately factors into our analysis and assessment of the feasibility of the proposed policy. We examine how the minimum eligibility age and the duration of eligibility affect costs, and discuss the likely effects of other specification changes. 


\section{A. Modeling Program Eligibility Requirements}

We sought to use the HRS to identify a sample of older workers who would benefit from a program designed to assist them after they experience financial hardship as a result of a healthrelated work limitation. Our proposed policies are designed to help older workers who (1) have a health-related work limitation but are not receiving SSDI or SSI benefits, (2) would experience a substantial decline in earnings associated with that limitation under current law, and (3) would experience financial hardship as a result. ${ }^{6}$ This section presents how we identified the eligible population based on each of these criteria.

We first defined the "potentially eligible" sample from the 1940-1941 birth cohort in each HRS year as those from that cohort who reported a health-related work limitation but did not report receiving SSDI or SSI benefits (as shown in Table II.1). We then impose additional eligibility criteria. The first of these is age. Because of the HRS design, the lowest age we can consider is 51 . We also illustrate the effects with a higher minimum age, using 55 and 60. In all cases, the upper age limit is 64 .

A real program would impose additional criteria for eligibility. Our assumption is that such a program would seek to exclude those who, in the absence of the program, would not experience a large earnings loss associated with their limitation, as well as those who would not experience financial hardship despite a large earnings loss. Use of explicit earnings loss and income tests would be a mistake, however, for two reasons.

First, the goal of the program is to keep workers who experience health-related work limitations in the labor force so that they do not experience large earnings losses and financial hardship.

\footnotetext{
${ }^{6}$ Considering both declines in earnings and being in poverty is similar in spirit to the Rockefeller Economic Security Index developed by Hacker et al. (2010), http://www.rockefellerfoundation.org/news/publications/moreamericans-are-financially-insecure. Admittedly, our measure does not take into account the potentially protective effect of assets as a buffer to income losses.
} 
Requiring that they actually experience either or both before they are determined eligible would undermine achievement of that goal. Second, if eligibility were based on actual earnings and income, it would likely distort the behavior of some workers. For example, someone who expected his or her earnings to fall by 45 percent could readily achieve a 50 percent reduction for purposes of becoming eligible, or a household with income just above the program's income threshold might find ways to hide some income. Such gaming can be avoided by using immutable predictors of financial hardship resulting from earnings loss - that is, personal characteristics that cannot readily be changed by the worker for purposes of gaining eligibility.

We are not able to develop the specifications for real-world eligibility criteria using survey data alone. We are, however, able to use the survey data to illustrate how such criteria would work. The approach we take relies on immutable personal characteristics or work history experiences that affect the likelihood that a worker who reports a health-related work limitation would experience material hardship because of an associated drop in earnings under current law. We develop an econometric model that captures this idea.

To develop the eligibility model, we turned to the HRS sample used by Schimmel and Stapleton (2010) that includes only those from all birth cohorts in the HRS sample who first reported a healthrelated work limitation in the second through fifth wave of the HRS and who were age 53 to 64 at the time. Those who reported a limitation in their first interview were excluded because we do not have data on their earnings prior to onset. ${ }^{7}$ We also excluded the small share that did not have earnings data in either the interview before or the one after the interview in which they first reported

${ }^{7}$ For the 1940-1941 cohort, 17 percent reported a health-related work limitation during their first HRS interview, when they were 51 or 52 . Because they were older, members of birth cohorts were more likely to report limitations at their first interview. 
a limitation, as well as those missing any other data needed for the analysis. ${ }^{8}$ The resulting sample included 846 respondents, representing 2.1 million individuals in the population.

We identified which of these individuals experienced earnings declines of at least 50 percent from the wave before they first reported the onset of health-related work limitation to the wave following that report-a four-year span. ${ }^{9}$ This group suffered relatively large losses in earnings coincident with their first report of a work limitation, although we cannot determine for certain that the earnings declines occurred as a direct result of the onset of the limitation.

We defined financial hardship on the basis of household income relative to the federal poverty line (FPL), measured in the wave after onset. ${ }^{10}$ For illustrative purposes, we specified 200 percent of FPL as the threshold for financial hardship.

We estimated that 64 percent of those who experienced a work limitation between the age of 53 and 64 also experienced an earnings decline of 50 percent or more. Of the latter group, just under 50 percent had household income of less than 200 percent of the FPL in the wave after onset. Hence, of those who reported a limitation, 30 percent (representing 642,000 people) experienced both a large earnings decline and financial hardship, based on the definitions used.

In designing our model, we sought to include factors to predict the likelihood of hardship from an earnings decline that might plausibly be used in an actual program. We wanted to exclude factors that could be changed or misreported in order to gain entry into the program or that relied on the

\footnotetext{
8 Of the 1,019 individuals in that sample, 846 (83 percent of the weighted sample) had the data needed for this analysis.

${ }^{9}$ We also considered earnings losses of 25 percent or more, though we found that only 4.6 percent of the sample had earnings losses between 25 and 49 percent and most had earnings fall to zero in the period after onset. For this reason, we focused on 50 percent or more as a more stringent version of earnings declines.

10 We also considered 100, 150, and 300 percent of the FPL; the selection of 200 percent ultimately was somewhat arbitrary. Selecting 100 percent would have reduced the size of the target population and focused on those most in need; 300 percent would have included some households that were not as disadvantaged and would have increased the size of the target population. For example, using the 200 percent criteria, 47.3 percent of those experiencing a drop in earnings of 50 percent or more met the additional criteria. This would have been 34.7 percent if we had instead selected 150 percent of FPL, or 64.6 percent if we had selected 300 percent of FPL.
} 
extensive collection of information from applicants. ${ }^{11}$ The specification used in the reported analysis is a logistic regression model for the probability that a worker who reports a health-related work limitation will experience financial hardship (household income below 200 percent of the FPL) and an earnings decline of at least 50 percent, with the following predictors (that is, explanatory variables): age at onset, marital status (married or not), educational attainment (less than high school, high school graduate, some college, college graduate), and occupational category (in 17 different categories). Marital status is an exception to our rule of excluding mutable predictors. Its inclusion reflects the fact that it is used in determining an individual's tax status. We also opted to exclude three immutable factors, namely gender, race, and veteran status, because preferential treatment based on these variables is politically problematic. ${ }^{12}$

The model's odds ratios are reported in Table III.1. Those with higher educational attainment are less likely to experience hardship associated with an earnings decline, as are those who are married. Other things constant, each year of age increases the odds by an estimated seven percent. Most of the effects for occupational category are not statistically significant, reflecting the effects of small sample size in many of the categories. Relative to those in managerial occupations, those in sales and service occupations are significantly more likely to experience hardship associated with an earnings decline; the estimates for other occupations indicate an increased risk as well, but are not statistically significant.

11 For example, the characteristics of one's most recent job, such as whether the job required good eyesight or heavy lifting, were available in the HRS and might have been good predictors of the likelihood of experiencing hardship for some. However, for those whose limitation predated the start of the HRS, this information may not have been of as much value, since it would have been many years old.

12 A model that did include such factors did not substantially improve predictive power. 
Table III.1. Estimated Odds Ratios from Logit Model Predicting the Likelihood of Experiencing Economic Hardship Associated with an Earnings Decline Following Work Limitation Onset

\begin{tabular}{lccc}
\hline & Odds Ratio & Standard Error & P-Value \\
\hline Education & & & \\
Less than high school & 2.73 & 0.57 & 0.00 \\
High school graduate (omitted) & 1.00 & - & - \\
Some college & 0.74 & 0.18 & 0.21 \\
College graduate & 0.55 & 0.17 & 0.05 \\
Marital Status (one wave after onset) & & & \\
Not married (omitted) & 1.00 & - & 0.00 \\
Married & 0.33 & 0.06 & 0.02 \\
Age in Years (one wave after onset) & 1.07 & 0.03 & \\
Occupational Category & & & - \\
Managerial (omitted) & 1.00 & - & 0.85 \\
Professional & 0.93 & 0.34 & 0.03 \\
Sales & 2.38 & 0.97 & 0.45 \\
Clerical/ administrative & 0.77 & 0.26 & 0.02 \\
Service: private households/ cleaning & 5.37 & 3.89 & 0.56 \\
/building services & & & 0.92 \\
Service: protection & 0.65 & 0.48 & 0.22 \\
Service: food & 0.95 & 0.46 & 0.46 \\
Health & 1.86 & 0.93 & 0.43 \\
Personal & 1.38 & 0.59 & 0.71 \\
Farming/forestry/fishing & 1.55 & 0.86 & 0.36 \\
Mechanics/ repair & 1.19 & 0.55 & 0.61 \\
Construction trade/ extractors & 1.52 & 0.69 & 0.29 \\
Precision production & 1.25 & 0.53 & 0.55 \\
Operators: machine & 1.49 & 0.56 & 0.36 \\
Operators: transport, etc. & 1.28 & 0.54 & 0.48 \\
Operators: handlers, etc. & 1.54 & 0.73 & 0.85 \\
Armed forces & 0.46 & 0.50 & \\
Occupation missing/ unknown & 0.88 & 0.61 & \\
\hline
\end{tabular}

Source: $\quad$ Authors' calculations using the 1992- 2008 HRS.

Notes: $\quad$ Occupational categories are based on longest job worked by the initial HRS interview in 1992 and are categorized using the 1980 Census occupational codes.

The predicted probabilities from this model were used to determine the eligible population in each of the simulations reported later. First, however, we needed to establish an eligibility threshold - the smallest value for the predicted probability that would make a worker eligible. To support the choice of a value, we examined the consequences when applying the model to the estimation sample, varying the cutoff from 0.1 to 0.7 in intervals of 0.1 . For each cutoff, we determined what proportion of the sample was incorrectly classified as having household income below 200 percent of FPL and an earnings decline of at least 50 percent. 
Nearly all of the workers in the population represented by the estimation sample would be eligible if the cutoff is set to 0.1 (2.0 out of 2.1 million), as shown in Table III.2. Increasing the cutoff rapidly reduces the number eligible-under 1.0 million for a cutoff of 0.3 and just over 100,000 for a cutoff of 0.7 . For comparison purposes, recall that those in the sample that actually meet both the income and earnings reduction criteria represent 642,000 workers in the population.

Table III.2. Likelihood of Type I and Type II Error Using Eligibility Model to Predict the Probability of Experiencing Hardship Around the Onset of Work Limitation

\begin{tabular}{|c|c|c|c|c|c|}
\hline $\begin{array}{l}\text { Threshold: } \\
\text { Predicted } \\
\text { Probability }>\text { X }\end{array}$ & $\begin{array}{l}\text { Total Number Eligible } \\
\text { for Program, as } \\
\text { Determined By Model } \\
\text { (Thousands) }\end{array}$ & $\begin{array}{l}\text { Number of } \\
\text { False } \\
\text { Positives } \\
\text { (Thousands) }\end{array}$ & $\begin{array}{c}\text { False } \\
\text { Positives as } \\
\text { Percent of } \\
\text { Those Not in } \\
\text { Hardship }\end{array}$ & $\begin{array}{l}\text { Number of } \\
\text { False } \\
\text { Negatives } \\
\text { (Thousands) }\end{array}$ & $\begin{array}{c}\text { False } \\
\text { Negatives as } \\
\text { Percent of } \\
\text { Those in } \\
\text { Hardship }\end{array}$ \\
\hline \multicolumn{6}{|c|}{ Predicting hardship using age, marital status, occupation, and education } \\
\hline $\begin{array}{l}X=0.1 \\
X=0.2 \\
X=0.3 \\
X=0.4 \\
X=0.5 \\
X=0.6 \\
X=0.7\end{array}$ & $\begin{array}{r}2,008 \\
1,391 \\
905 \\
630 \\
390 \\
185 \\
112 \\
\end{array}$ & $\begin{array}{r}1,372 \\
836 \\
467 \\
296 \\
154 \\
57 \\
30 \\
\end{array}$ & $\begin{array}{r}93.3 \\
56.9 \\
31.8 \\
20.1 \\
10.5 \\
3.9 \\
2.0 \\
\end{array}$ & $\begin{array}{r}6 \\
88 \\
205 \\
308 \\
406 \\
515 \\
566 \\
\end{array}$ & $\begin{array}{r}1.0 \\
13.7 \\
31.9 \\
48.0 \\
63.2 \\
80.2 \\
87.3 \\
\end{array}$ \\
\hline
\end{tabular}

Source: $\quad$ Authors' calculations based on the 1992- 2008 HRS.

Notes: The analysis sample is limited to those who reported new work limitation onset for the first time between HRS waves 2-5 and for whom data was available to construct our hardship measure. Hardship associated with an earnings decline following work limitation onset is defined as household income less than 200 percent of FPL along with an earnings decline around the time of onset of at least 50 percent.

The likelihood of Type I errors (false positives) and Type II errors (false negatives) depends on the cutoff selected; there is a tradeoff between the two. For example, 49.4 percent of those with a predicted probability greater than 0.2 were false positives; that is, they did not experience both an earnings decline of at least 50 percent and household income below 200 percent of FPL. A threshold of 0.3 cuts the number of false positives in half and reduces the percentage of false positives to 31.8 percent. But the number of false negatives moves in the opposite direction. Of the approximately 642,000 who experienced hardship, nearly 88,000 (13.7 percent) were incorrectly excluded using the limited model and a threshold of 0.2; this number rose to nearly 205,000 (31.9 percent) when using a threshold of 0.3 in the limited model. At a threshold of 0.4 and higher, half or 
more of those who experienced hardship would not have been included in the target population for the program.

With better data, it might be possible to greatly improve the tradeoff between Type I and Type II errors; that is, to exclude few who are destined to experience hardship as the result of a large earnings decline without including many who are not. Given the tradeoff available for the simulations, we judged that a cutoff below 0.2 would be too low because of the large number of false positives, while a cutoff above 0.3 would be too high because of the large number of false negatives.

It is important to recognize that false positives are not random draws from all those who would not experience hardship from an earnings decline associated with their work limitation, and that false negatives are not random draws from those who would. The model is expected to produce false positive cases that are more likely to experience earnings declines and hardship than true negative cases, but less likely than true positive cases. This is confirmed in Table III.3. For example, under a threshold of 2.0, 15.0 percent of the false positive cases had incomes below 200 FPL compared to just 3.5 percent of the true negative cases. A similar pattern for earnings declines showed that false positives were more similar to true positives than to true negatives. Symmetrically, the incomes and earnings declines experienced by the false negatives are between those experienced by the true positives and the true negatives.

We also examined mortality prior to age 65 for four groups. Not surprisingly, mortality is higher among the true positives and false negatives than among the false positives and true negatives. There is no significant difference between mortality for true positives and false negatives or between false positives and true negatives. 
Table III.3. Comparison of Household Poverty Status, Earnings Declines, and Mortality Among Workers Experiencing Work Limitation Onset, Based on Program Eligibility Status as Determined by the Eligibility Model

\begin{tabular}{|c|c|c|c|c|}
\hline & True Positive & False Positive & True Negative & False Negative \\
\hline \multicolumn{5}{|c|}{ Threshold: Predicted Probability > 0.2} \\
\hline $\begin{array}{l}\text { Income Relative to } \mathbf{P} \\
<100 \text { percent } \\
100-149 \text { percent } \\
150-199 \text { percent } \\
200-299 \text { percent } \\
300 \text { percent or more }\end{array}$ & $\begin{array}{r}\text { (percent) } \\
53.2 \\
24.1 \\
22.7 \\
0.0 \\
0.0\end{array}$ & $\begin{array}{r}4.0 \\
5.3 \\
5.7 \\
32.8 \\
52.1\end{array}$ & $\begin{array}{r}0.0 \\
0.7 \\
2.8 \\
18.8 \\
77.6\end{array}$ & $\begin{array}{r}19.7 \\
29.9 \\
50.4 \\
0.0 \\
0.0\end{array}$ \\
\hline $\begin{array}{l}\text { Earnings Decline (pe } \\
0-24 \text { percent } \\
25-49 \text { percent } \\
50-100 \text { percent } \\
\text { Earnings increase }\end{array}$ & $\begin{array}{r}0.0 \\
0.0 \\
100.0 \\
0.0\end{array}$ & $\begin{array}{r}19.3 \\
9.6 \\
42.6 \\
28.5\end{array}$ & $\begin{array}{r}12.6 \\
5.6 \\
56.8 \\
25.1\end{array}$ & $\begin{array}{r}0.0 \\
0.0 \\
100.0 \\
0.0\end{array}$ \\
\hline Death by Age 65 & 5.5 & 3.7 & 3.9 & 5.2 \\
\hline \multicolumn{5}{|c|}{ Threshold: Predicted Probability > 0.3} \\
\hline $\begin{array}{l}\text { Income Relative to } \mathrm{P} \\
<100 \text { percent } \\
100-149 \text { percent } \\
150-199 \text { percent } \\
200-299 \text { percent } \\
300 \text { percent or more }\end{array}$ & $\begin{array}{r}\text { (percent) } \\
58.3 \\
21.7 \\
20.0 \\
0.0 \\
0.0\end{array}$ & $\begin{array}{r}7.2 \\
7.0 \\
7.8 \\
34.4 \\
43.6\end{array}$ & $\begin{array}{r}0.0 \\
1.7 \\
2.9 \\
23.3 \\
72.2\end{array}$ & $\begin{array}{r}27.9 \\
31.7 \\
40.3 \\
0.0 \\
0.0\end{array}$ \\
\hline $\begin{array}{l}\text { Earnings Decline (pe } \\
0-24 \text { percent } \\
25-49 \text { percent } \\
50-100 \text { percent } \\
\text { Earnings increase }\end{array}$ & $\begin{array}{r}0.0 \\
0.0 \\
100.0 \\
0.0\end{array}$ & $\begin{array}{l}21.1 \\
12.2 \\
39.3 \\
27.4\end{array}$ & $\begin{array}{r}14.2 \\
5.9 \\
53.1 \\
26.8\end{array}$ & $\begin{array}{r}0.0 \\
0.0 \\
100.0 \\
0.0\end{array}$ \\
\hline Death by Age 65 & 5.3 & 3.5 & 3.9 & 5.8 \\
\hline
\end{tabular}

Source: Authors' calculations based on the 1992- 2008 HRS.

Notes: The analysis sample is limited to those who reported work limitation onset for the first time between HRS waves 2- 5 and for whom data was available in the waves around initial onset to construct the hardship measure.

\section{B. Size of the Eligible Population Under Various Eligibility and Duration Assumptions}

The next step was to use the eligibility model to examine the size of the eligible population in the years corresponding to each HRS wave for the 1940-41 birth cohort, under various assumptions about the minimum eligibility age, the duration of eligibility, and the cutoff value from the eligibility model. We used the model to calculate the predicted probability of hardship associated with an earnings decline for those with health-related work limitations at each HRS interview. We repeated this process from the first wave in which respondents were interviewed (age 51-52 in 1992) to the 
last wave when they were still under age 65 (Wave 7 in 2004, age 63-64). Appendix Table 1 contains the per-wave sample sizes under various assumptions. By following the $51-52$ cohort, we produced statistics for workers in every two-year age interval from 51-52 to 63-64. We then rescaled the statistics for each two-year age group to the 2010 population in that age group. ${ }^{13}$

As shown in Table II.4, the predicted probability thresholds lead to significant reductions in the number who would be eligible for the program, relative to allowing all who report a work limitation to participate. Overall, 8.3 million individuals, or 15.8 percent of the total population age $51-64$ in 2010, is estimated to have a work limitation without having DI or SSI coverage. Using predicted probabilities of hardship at the 0.2 and 0.3 thresholds reduces the size of the eligible population by approximately 40 to 50 percent.

Applying the predicted probability thresholds is not the only way to limit the size of the eligible population; other variants are shown in Table III.4. Most notably, rather than beginning program eligibility as soon as age 51, the program could instead cover only those who report a work limitation at age 55 to 64. Compared with a program where eligibility begins at age 51 and lasts as long as a work limitation is reported, starting eligibility at age 55 reduces program size by approximately one-third, while beginning it at age 60 reduces its size by about another 50 percent.

Another alternative is to place a time limit on eligibility. To illustrate a two-year time limit, we assumed that individuals are eligible for (1) the wave in which they first report a work limitation at or above a certain age and (2) two years (one wave) later. Eligibility in the second year would continue

\footnotetext{
13 Specifically, we calculated in each two-year interval from 1998 to 2010 the number of individuals who were age 51-52; those who survived to 2010 were in the 51-64 age range in 2010. We then calculated the number of 51-52-yearolds in each of these years relative to the number in 1992, resulting in the set of scaling factors. The following illustrates how they were applied. The estimated number of 51- to 52-year-olds in 2002 was equal to 1.59 times the number in 1992. Those in this age group in 2002 were ages 59-60 in 2010. Hence, we multiplied the statistics for 59- to 60-yearolds based on the HRS by 1.59 to obtain the estimate for those age 59-60 in 2010.
} 
Table III.4. Estimated Size of the Age 51-64 Eligible Population in 2010

\begin{tabular}{|c|c|}
\hline & $\begin{array}{l}\text { Population Size } \\
\text { (thousands) }\end{array}$ \\
\hline Total Population Size, Age 51-64, 2010 & 52,565 \\
\hline $\begin{array}{l}\text { Eligibility in all years of reported work limitation, age } 51-64 \\
\text { With work limitation, no DI/SSI } \\
\text { Predicted probability of hardship }>0.2 \\
\text { Predicted probability of hardship }>0.3\end{array}$ & $\begin{array}{l}8,324 \\
5,354 \\
3,739\end{array}$ \\
\hline $\begin{array}{l}\text { Eligibility in all years of reported work limitation, age 55- } 64 \\
\text { With work limitation, no DI/SSI } \\
\text { Predicted probability of hardship }>0.2 \\
\text { Predicted probability of hardship }>0.3\end{array}$ & $\begin{array}{l}5,848 \\
4,012 \\
2,928\end{array}$ \\
\hline $\begin{array}{l}\text { Eligibility in all years of reported work limitation, age } 60-64 \\
\text { With work limitation, no DI/SSI } \\
\text { Predicted probability of hardship }>0.2 \\
\text { Predicted probability of hardship }>0.3\end{array}$ & $\begin{array}{l}2,723 \\
2,085 \\
1,607\end{array}$ \\
\hline $\begin{array}{l}\text { Time- limited program; } 2 \text { years after first report, age } \mathbf{5 1 - 6 4} \\
\text { With work limitation, no DI/SSI } \\
\text { Predicted probability of hardship }>0.2 \\
\text { Predicted probability of hardship }>0.3\end{array}$ & $\begin{array}{l}5,929 \\
3,261 \\
2,042\end{array}$ \\
\hline $\begin{array}{l}\text { Time- limited program; } 2 \text { years after first report, age } 55-64 \\
\text { With work limitation, no DI/SSI } \\
\text { Predicted probability of hardship }>0.2 \\
\text { Predicted probability of hardship }>0.3\end{array}$ & $\begin{array}{l}4,639 \\
2,799 \\
1,907\end{array}$ \\
\hline
\end{tabular}

Source: $\quad$ Authors' calculations based on 1992-2008 HRS and U.S. Census Bureau (2010).

Note: $\quad$ The size of the eligible population is calculated based on the wave-specific values reported in Table III.3, after applying population scaling factors to arrive at the U.S. population age 51-64 in 2010.

regardless of whether a work limitation was still reported, provided the person remained alive, unless the worker entered SSDI or SSI in that wave. ${ }^{14}$ We considered two alternatives of a time-limited program; one that begins at the first report above age 50 and one that begins at the first report at or above age $55 .{ }^{15}$ Time-limiting the program for two years after first reported onset over age 50 or

14 Approximately 7 percent of those who first reported onset in one wave reported having DI or SSI in the subsequent wave. To adjust for this, we first calculated the number of individuals who would be eligible for the timelimited program in each wave, then reduced the sample size by 3.5 percent (since in each wave, the eligible sample is a mix of those who first reported onset in the previous and current wave). This simplification allowed us to overcome missing data for those who reported onset in one wave but were not interviewed in the subsequent wave (but were not determined to be dead).

15 We did not consider a time-limited alternative of the program that begins at age 60, instead assuming that the program would allow individuals to participate through age 64 . 
older reduces program size by 18 to 30 percent relative to allowing eligibility in all years over age 50, while time-limiting the program and beginning eligibility at age 55 reduces program size by about 7 to 22 percent relative to the program with the same age eligibility criteria but no time restriction. 


\section{DESIGNING POLICY OPTIONS}

In identifying policy options to assist older workers who experience hardship after the onset of a health condition limiting their ability to work, we sought to accomplish two goals: reduce the likelihood of hardship after onset and provide incentives to continue working. We accomplished this by considering three options: an EITC, an ESA, and a health insurance subsidy. In this section, we describe the motivation for and design of each option.

\section{A. Earned Income Tax Credit}

The EITC incentivizes work for those with little or no earnings because the amount of the subsidy increases with earnings. The EITC option we consider would offer to eligible workers the EITC currently available to households with three children, yielding a maximum credit of $\$ 5,666$. This is equivalent to approximately 40 percent of the mean loss in earnings experienced after onset. $^{16}$

The effect of the EITC for three-child households on income is depicted in Figure IV.1. ${ }^{17}$ Under this scheme, each dollar of earnings up to $\$ 12,590$ increases the credit by 45 cents. From $\$ 12,590$ to $\$ 16,450$, the credit is maximized; a person earning anywhere in this range receives the maximum credit amount of $\$ 5,666$. For earnings above $\$ 16,450$, the credit phases out at a rate of 21.05 cents for each dollar of earnings, meaning that those who earn more than $\$ 43,352$ receive no credit. $^{18}$

16 Stapleton and Schimmel (2010) estimate that the mean earnings loss two years after onset is approximately $\$ 14,000$. Under current law, most households in our target population would only be eligible for the credit for households with no children. The maximum credit for such households is just $\$ 457$.

${ }^{17}$ Information on the EITC was obtained from the Urban Institute and Brookings Institution Tax Policy Center (2010). Accessed at http://www.taxpolicycenter.org/taxfacts/displayafact.cfm?Docid=36.

${ }^{18}$ Current tax policy applies the EITC schedule to total earnings of married couples and uses thresholds that are $\$ 5,010$ higher than those shown in the exhibit. The findings we report apply the depicted schedule to the worker's own earnings, without regard to the spouse's earnings. We analyzed a variant that allowed married individuals to use this EITC for couples with three children instead of the EITC based only on their own earnings; this increased the cost of the program under the assumption of no change in earnings in response to the policy, because individuals with no 
Figure IV.1. Proposed EITC for Older Workers with Disabilities

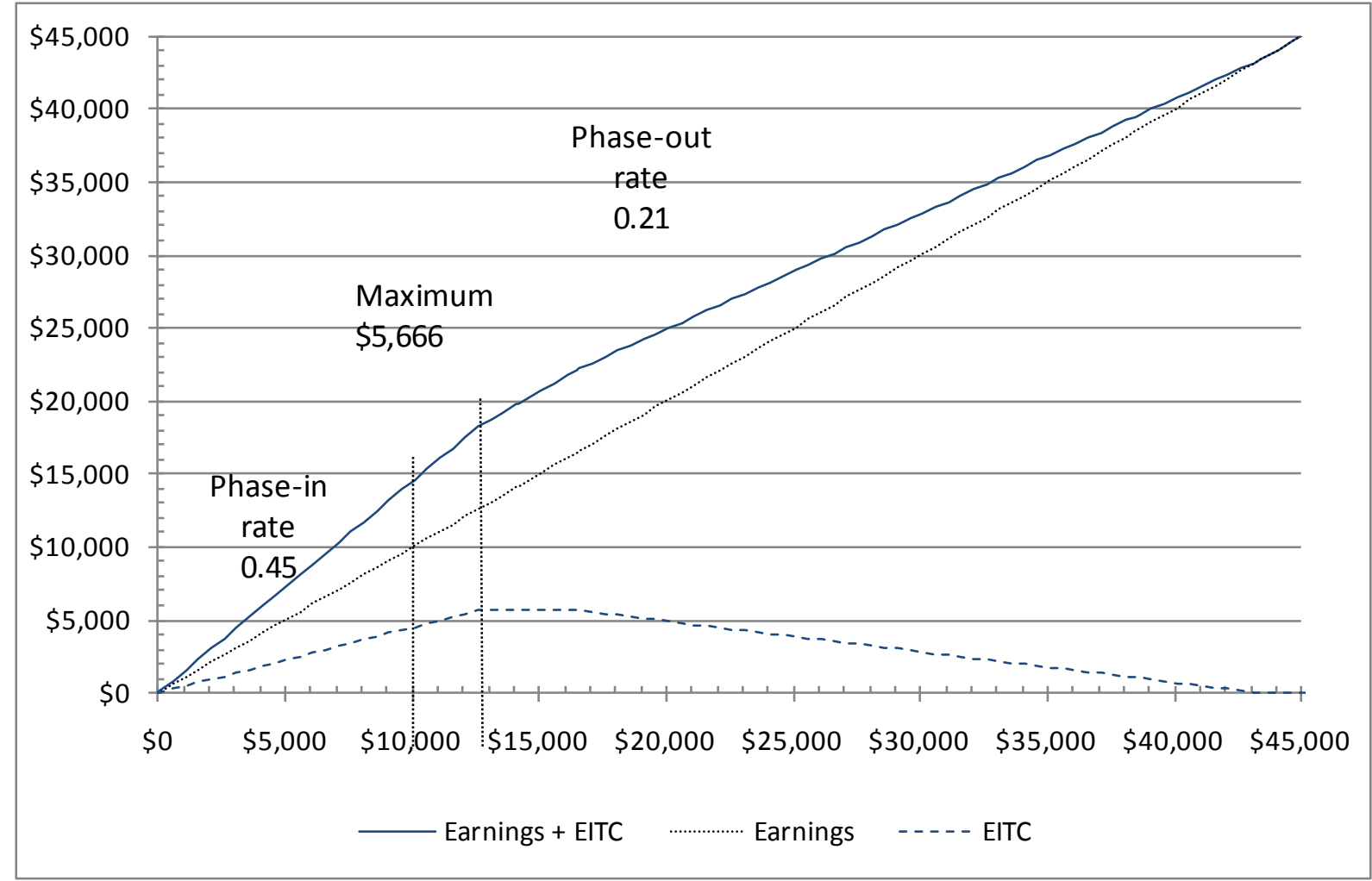

A large body of evidence, summarized in Eissa and Hoynes (2005), has demonstrated that the EITC affects labor supply and. in particular, the extensive margin (decision to work) more than the intensive margin (how many hours to work). We expect a similar behavioral response from older workers, meaning that the introduction of a subsidy program for those with work limitations is expected to induce them to continue working. However, the extent to which the introduction of an EITC for older workers with disabilities might reduce labor force exit is not known.

To specify the magnitude of an earnings increase resulting from the EITC, we again turned to the matched sample used in Schimmel and Stapleton (2010). In that analysis, we found that those

\section{(continued)}

earnings often were able to get some credit based on the earnings of their spouse. Costs were lower, however, when the worker's earnings were assumed to increase by the maximum amount considered, because spousal earnings made it more likely that the couple's earnings would be in or above the phase-out range. 
who experienced work limitation onset had reduced earnings from the wave of onset to two waves later that were approximately $\$ 12,000$ lower per year than those in the comparison sample who did not experience onset. Using this amount, we considered two behavioral responses: one where those who had no earnings under current law instead earn an amount equal to 25 percent of the average decline in earnings after onset (approximately $\$ 3,000$ ); and one where earnings among non-earners under current law are, instead, 50 percent of the decline in earnings after onset (approximately $\$ 6,000) \cdot{ }^{19}$ We recalculated the EITC under both earnings scenarios.

\section{B. Employment Service Allowance}

The second option would offer an allowance for employment services, the ESA. This could be structured in many ways. One approach would provide an allowance, up to a limit, for documented expenditures on goods and services that meet specified criteria. We think this approach would be administratively burdensome and would encourage inefficient purchases of goods and services. At the opposite extreme, the allowance could be paid without requiring documentation, similar to disability allowances intended to defray the extra costs of disability that are currently available in several European countries. We think the latter type of allowance is likely to be much more efficient and easier to administer. A hybrid would tailor the size of the allowance to the individual's circumstances, evaluated at enrollment and perhaps re-evaluated annually, but not restrict how the allowance is used.

As a guide to the appropriate amount for an allowance, we turned to the Ticket to Work (TTW) program. TTW is a performance-based voucher that SSDI and SSI beneficiaries may use in support

${ }^{19}$ We considered variants to these alternatives where all earners had earnings increases that were 25 or 50 percent of the decline in earnings after onset. These variants did not substantially change our estimates of the program costs or effects on poverty. Because the EITC has been shown to alter the extensive margin more than the intensive margin, we focus on the scenario where the earnings increases are experienced only by those whose earnings have fallen to zero without the program. 
of their efforts to return to work and leave the disability rolls. Participants in the program may assign their "Ticket" to any qualified provider that will accept it in return for employment services. There are no restrictions on the nature of the services provided.

Each TTW provider may choose from one of two payment systems. Under one of these, the outcome-only system, SSA pays the provider a specified amount—an "outcome payment"—in every month that the beneficiary is off the rolls because of work, up to a maximum number of months. In 2010 , the monthly outcome payment amount for SSDI beneficiaries was $\$ 711$ ( $\$ 8,532$ annually). The maximum number of payments is 36 . We use the annual amount as the upper bound for the allowance, but only impose a time limit under scenarios with duration limits on eligibility. Presumably those eligible for the allowance would typically need fewer services to remain at work than SSDI beneficiaries need to return to work.

It is worth noting that one service TTW providers are allowed to offer is conversion of outcome payments into cash payments to the beneficiary. The beneficiary may use the cash without restriction. In essence, the beneficiary is being provided with a financial incentive to leave the rolls for work. Analogously, the ESA can be viewed as a financial incentive to remain in the labor force and not enter SSDI.

\section{Health Insurance Subsidy}

The third option we consider is a subsidy to purchase health insurance. Lacking health insurance coverage in the years prior to retirement is less likely than at younger ages (Employee Benefit Research Institute 2009). However, those who experience the onset of a new work-limiting health condition may be more likely than others to lose their employer-sponsored coverage—at precisely the time when they most need health insurance. Lack of coverage could itself create financial hardship, even if there is no impact on household income. Further, those who lack coverage entirely may not seek appropriate care, which could reduce their earnings and make it more 
likely that they have pent-up demand for health services when they reach age 65 and become eligible for Medicare (McWilliams et al. 2003; Chen et al. 2004; Schimmel 2005; McWilliams et al. 2007a; McWilliams et al. 2007b).

A health insurance subsidy would help address the financial hardship that might result from increased need for health services or possible loss of employer coverage. It would also help workers obtain services they might need to continue to work. We specify a subsidy based on provisions in the Patient Protection and Affordable Care Act (ACA) of 2010. Under the ACA, households would receive tax credits to purchase health insurance through health insurance exchanges if they are not eligible for employer coverage. In our scheme, those with household incomes below 400 percent of poverty would be paid a subsidy equal to the difference between an estimate of the full premium for their coverage and a percentage of household income, following the schedule in Table IV.1. The subsidy is provided to every eligible worker without regard to whether the worker is eligible for employer coverage. $^{20}$

\section{Table IV.1. Premium Contributions as a Share of Income Based on the ACA Provisions}

\begin{tabular}{ll}
$\begin{array}{l}\text { Household Income } \\
\text { Relative to FPL }\end{array}$ & \multicolumn{1}{c}{$\begin{array}{c}\text { Maximum Share of Income to Be Paid } \\
\text { for Health Insurance Premiums }\end{array}$} \\
\hline Up to 133 percent & 2 percent \\
133 to 150 percent & $3-4$ percent \\
150 to 200 percent & $4-6.3$ percent \\
200 to 250 percent & $6.3-8.05$ percent \\
250 to 300 percent & $8.05-9.5$ percent \\
300 to 400 percent & 9.5 percent \\
\hline
\end{tabular}

Source: $\quad$ Kaiser Family Foundation 2010a.

The premium amount used is based on a survey conducted in 2010 of individuals who purchased non-employer coverage (Kaiser Family Foundation 2010b). The average amount paid for

\footnotetext{
${ }^{20}$ We will consider the effect of restricting the subsidy to those without insurance from their own employer or that of a spouse in a future revision.
} 
individual coverage for those age 55-64 was $\$ 4,822$. The health insurance subsidy was calculated as the difference between $\$ 4,822$ and the maximum premium to be paid.

The cost of the health insurance subsidy could arguably be excluded as a cost of benefits to eligible workers under a new program, because it presumably will be available to them under the ACA. Those provisions are not yet in place, however, and could change. Hence, it is important to consider how the subsidies would affect program costs if they are considered to be part of the program. 


\section{ANALYSIS OF POLICY OPTIONS: TOTAL COST, FISCAL VIABILITY, AND POTENTIAL TO REDUCE POVERTY}

\section{A. Costs of Program Components Under Various Scenarios}

The total cost of a program designed to assist older workers experiencing health-related work limitations depends on the size and characteristics of the population eligible for the program and the generosity of the program. In Table V.1, we show program costs under three sets of cost assumptions that we applied to two variants of the eligible population, as shown in Table II.4. ${ }^{21}$ Specifically, under the most restrictive eligibility criteria considered in Table V.1, the minimum eligibility age is 55 , eligibility is time limited, and the predicted probability of hardship must exceed 0.3. Under the least restrictive eligibility criteria, the minimum age is 51 , there is no time limit, and the predicted probability of hardship must only exceed 0.2 .

The least expensive option shown in Table V.1 assumes no behavioral response to the EITC, no health insurance subsidy, and an employment services allowance that is only 25 percent of the full Ticket payment amount. The most expensive option assumes that earnings of those without earnings under current policy would increase by 50 percent of the average decline in earnings after onset, the full health insurance subsidy is included in the program, and the ESA for all eligible workers is equal to the maximum annual T'TW payment amount.

The total cost of the least expensive program ranges from $\$ 6.3$ billion annually, assuming the most restrictive eligibility criteria apply, to $\$ 16.3$ billion, assuming the least restrictive criteria apply. The corresponding range for the most expensive program is $\$ 28.1$ billion to $\$ 78.1$ billion.

\footnotetext{
${ }^{21}$ Appendix Table 2 shows the total cost of each program component using the full set of possible eligible populations shown in Table 4. All cost analyses have been updated to 2010 dollars using the Consumer Price Index.
} 
Table V.1. Program Costs for Least Expensive, Intermediate, and Most Expensive Options Under More and Less Restrictive Eligibility Criteria

\begin{tabular}{|c|c|c|c|}
\hline & Least Expensive & Intermediate & Most Expensive \\
\hline EITC & $\begin{array}{l}\text { No behavioral } \\
\text { response }\end{array}$ & $\begin{array}{l}25 \text { percent increase in } \\
\text { earnings }\end{array}$ & $\begin{array}{l}50 \text { percent increase } \\
\text { in earnings }\end{array}$ \\
\hline Health insurance subsidy & None & $\begin{array}{l}50 \text { percent of } A C A \\
\text { subsidy }\end{array}$ & Full \\
\hline Employment services allowance & $\begin{array}{l}25 \text { percent of full } \\
\text { Ticket payments }\end{array}$ & $\begin{array}{l}50 \text { percent of full } \\
\text { Ticket payments }\end{array}$ & Full \\
\hline \multicolumn{4}{|l|}{$\begin{array}{l}\text { More Restrictive Eligibility } \\
\text { Criteria' }\end{array}$} \\
\hline $\begin{array}{l}\text { Total cost } \\
\text { Average per capita cost } \\
\text { Poverty rate }\end{array}$ & $\begin{array}{l}\$ 6.3 \text { billion } \\
\$ 3,277 \\
32.7\end{array}$ & $\begin{array}{l}\$ 15.2 \text { billion } \\
\$ 7,719 \\
21.0\end{array}$ & $\begin{array}{l}\$ 28.1 \text { billion } \\
\$ 14,689 \\
9.0\end{array}$ \\
\hline \multicolumn{4}{|l|}{$\begin{array}{l}\text { Less Restrictive Eligibility } \\
\text { Criteria }^{2}\end{array}$} \\
\hline $\begin{array}{l}\text { Total cost } \\
\text { Average per capita cost } \\
\text { Poverty rate }\end{array}$ & $\begin{array}{l}\$ 16.3 \text { billion } \\
\$ 3,111 \\
31.8\end{array}$ & $\begin{array}{l}\$ 41.5 \text { billion } \\
\$ 7,916 \\
20.8\end{array}$ & $\begin{array}{l}\$ 78.1 \text { billion } \\
\$ 14,633 \\
7.7\end{array}$ \\
\hline
\end{tabular}

Source: $\quad$ Authors' calculations based on the 1992- 2008 HRS.

${ }^{1}$ More restrictive eligibility criterion is a time- limited program following the first reported onset from age 55 to 64, where only those with a predicted probability of hardship of greater than 0.3 would be eligible. See Section III.3 for details.

2 Less restrictive eligibility criterion offers the program to all those reporting work limitation between age 51 and 64, in all periods when a limitation reported and the probability of experiencing hardship is greater than 0.2. See Section III.3 for details.

Under both eligibility scenarios, per capita costs in the least expensive program are just over $\$ 3,000$. Under the most expensive program, per capita costs are more than four times as large, nearly $\$ 15,000$ under either the most or least restrictive eligibility criteria. Excluding the health insurance credit would reduce the cost of the most expensive program to about $\$ 11,000$.

Our assumptions reflect several factors that will affect program costs. The first is the effect of the program on earnings, which in turn affects the cost of the EITC. If earnings are unchanged, the EITC is relatively inexpensive because a very large share of eligible beneficiaries has no earnings, but if earnings increase by the maximum amount considered, the EITC is much more expensive. Second, the health insurance subsidy could be excluded or not counted as a cost. Third, the ESA 
payments could be scaled back to a fraction of the maximum annual amount of TTW outcome payments.

Another factor that will affect cost is take-up. We have assumed 100 percent take-up. The effect of lower take-up on costs would be similar to the effect of making the eligibility criteria stricter (that is, increasing the lower bound for the predicted probability of hardship from earnings loss).

\section{B. Comparison to Alternatives}

The political appeal of a work-support program will in part depend on its costs relative to alternative programs. Per capita annual costs under even the most expensive scenario are low relative to the most widely recognized program, SSDI. The per capita cost of the EITC and ESA would be less than per capita SSDI benefits for this age group even under the most expensive scenario considered. Annual SSDI cash benefits are approximately $\$ 14,855$ per capita for those who receive their award between the age of 50 and $64 .{ }^{22}$ When the cost of Medicare is added to SSDI costs for those who have received SSDI for 24 months, the difference is even larger; per capita annual Medicare cost plus SSDI benefits for this group are an estimated $\$ 25,855 .{ }^{23}$ Even if the costs of the health insurance subsidy did accrue to the work-support program, the per capita cost of the program would be much lower than the cost of SSDI plus Medicare.

A full accounting of the impact of a work-support program in the context of broader retirement policy reforms must consider many other factors, however. A full accounting would calculate the impact of the new program and the broader retirement policy reforms on the present value (PV) of benefit costs net of tax payments for all eligible workers. Such an accounting would require

22 Based on Table 36 of SSA (2010a). The table reports mean monthly benefits for new awardees in 2009 by age. The amount reported in the text is the weighted mean for three age groups, 50-54, 55-60, and 60-64, with weight proportional to the number of awards in each group.

${ }^{23}$ Dahl and Meyerson (2010) estimate that mean costs for Medicare benefits provided to eligible SSDI beneficiaries are approximately $\$ 11,000$ per year. 
specification of the retirement policy reforms. The direction of the impact will depend critically on the specifics of the retirement policy reform, the eligibility criteria for the work-support program, and the generosity of the work program's benefits.

The following simple example illustrates that a modest work-support program starting at age 60 in the context of a commonly discussed retirement policy reform need cost no more than a program that preserves the benefits of eligible workers. Assume that:

- The work-support program limits eligibility to workers age 60 through 63 and the annual cost is $\$ 6,000$ per capita (for example, an EITC with an average credit of $\$ 2,500$ coupled with an ESA of $\$ 3,500$ ). The PV at age 60 of this benefit is $\$ 23,004{ }^{24}$

- The retirement policy reform raises the EEA from 62 to 64 and other changes (such as an increase in the FRA) reduce lifetime benefits by an amount that is equivalent to the PV as of age 60 of two years' worth of the mean benefit paid in 2009 to retired beneficiaries age 62 to 64; $\$ 12,144$ (SSA 2010b). This is approximately what would happen if both the EEA and FRA were increased by two years, the computation of benefits at the FRA and EEA was not changed, and any increases in contributions to payroll tax revenues were not converted into higher benefits later on. The PV of the benefit reduction is $\$ 22,615$.

In this example, the PV of programmatic cost increases by $\$ 389$ per eligible worker, or about $\$ 100$ per year. Hence, from a cost perspective, the work-support program would be slightly more expensive than just preserving the benefits of the eligible population—a difference that is very small given the crude nature of the estimates. Compared to the benefit preservation alternative, however, the work preservation program would generate additional payroll taxes, because of increased earnings and reduced participation in SSDI. Given the current total OASDI and Medicare payroll tax rate of 15.3 , each $\$ 1,000$ increase in mean annual earnings would increase payroll tax revenue by \$153. For every worker who enters the work-support program rather than SSDI at age 60, the PV of

\footnotetext{
24 The discount rate used is 2.9 percent, the rate currently used by SSA's actuaries.
} 
the reduction in SSDI and Medicare benefits through age 63 would be an estimated $\$ 47,123 .^{25}$ Hence, it is at least plausible that, for those eligible, a modest work-support program would cost no more than a benefit preservation program.

\section{Impact on Financial Hardship}

Holding cost constant, the attractiveness of a work-support program relative to a benefit preservation program depends on the relative effectiveness of the two programs in helping workers with health-related work limitations avoid financial hardship. The work-support program is likely to be more successful in that regard because it rewards work, whereas early retirement benefits can discourage work because of the early retirement earnings test. The difference in incentives is illustrated in Figure V.1.

Under current law, an earnings test applies to early retirement benefits; for those age 62 to 64 , benefits are reduced by $\$ 1$ for every $\$ 2$ of annual earnings in excess of $\$ 14,160$ — that is, a benefit reduction rate of 0.5 is applied to earnings above this amount. ${ }^{26}$ The relationship between the retirement benefit and earnings for a worker with the mean annual benefit is depicted by the line labeled "SSR"; total income from benefits and earnings is depicted by the line labeled “earnings + SSR." Although the reduction in benefits for earnings above $\$ 14,160$ leads to actuarially fair increases in benefits at later ages, that tradeoff might not be very attractive to workers with relatively short life expectancies trying to avoid financial hardship. In contrast, the EITC, as

25 The PV of SSDI benefits for an individual who enters SSDI at age 60 and remains on SSDI through age 66 is estimated at $\$ 60,256$, under the assumption that the annual benefit is $\$ 13,500$. If the early retirement age were raised to 64, this same individual would be entitled to retirement benefits at age 64 . We assume those benefits would be 80 percent of the SSDI benefit, or $\$ 10,800$ per year, with a PV at age 60 of $\$ 28,092$. The SSDI beneficiary would be eligible for Medicare at age 62 instead of age 65 (the Medicare Eligibility Age is assumed unchanged). Assuming an average annual cost of $\$ 11,000$, the PV at age 60 of the Medicare benefit from ages 62 to 64 is $\$ 30,296$. The PV of the savings from diverting a worker from SSDI into the work-support program is calculated as (PV of SSDI from age 60 to age 65) - (PV of retirement benefit at ages 64 and 65) + (PV of Medicare at ages 62 through 64) - (PV of work-support program from age 60 to 65$)=\$ 70,759-\$ 30,927+\$ 30,296-\$ 23,004=\$ 47,123$.

26 See SSA (2010b). A smaller reduction applies to those age 65, and no reduction applies to those age 66 (the FRA) and older. 
depicted, is an earnings subsidy for eligible workers earning less than $\$ 43,352$; the amount of the ESA does not depend on earnings_assumed to be $\$ 3,500$ in this example. The line labeled "earnings + EITC + ESA" shows how total income from benefits and earnings varies with earnings under this program. The benefit reduction rate for earnings above $\$ 14,160$ is much lower under the work-support program than under early retirement benefits; it never exceeds 0.21 , the EITC phaseout rate.

Figure V.1. Comparison of Incentives Under a Work-Support Benefit and Current- Law Early Retirement Benefits

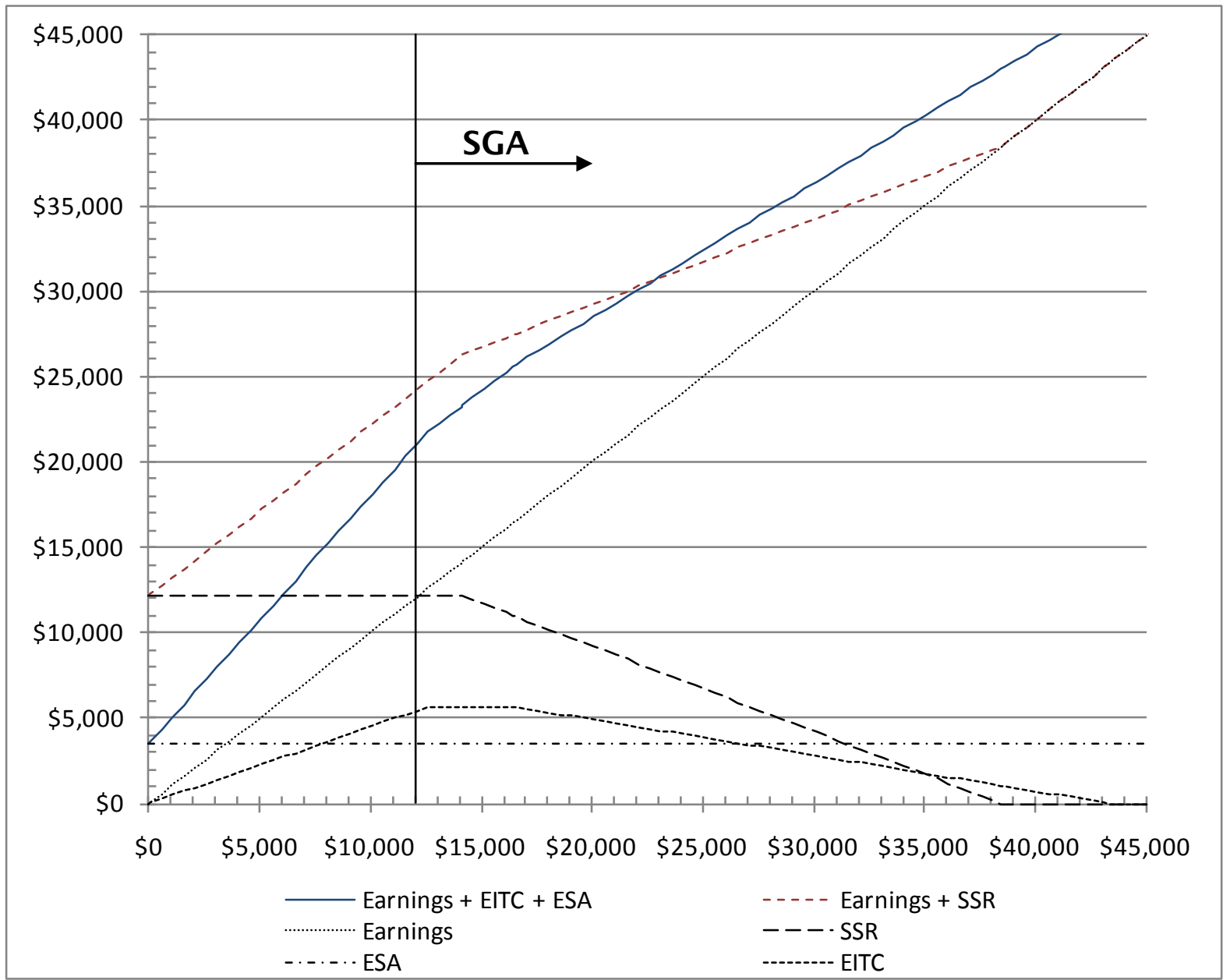

For the employment support program depicted, total income from earnings and benefits falls below total income from earnings and benefits for the mean early retiree if earnings are below about $\$ 23,000$, but the opposite is true for earnings above that amount. Thus, this work-support program 
offers the opportunity for higher income from earnings and benefits than can be achieved by the average early retiree for those able and willing to earn more than $\$ 23,000$, at the expense of lower benefits for those earning less. This is, however, of little consequence for those unable to earn more than $\$ 12,000$ per year-the annual equivalent of SSA's SGA amount-because they would likely qualify for SSDI.

Simulations of the effects of variations of a work-support program on the poverty status of those under age 65 , conditional on current law, demonstrate such a program's potential for poverty reduction. We estimate that in 2010 as many as 45 percent of those with a work limitation between age 51 and 64 are in poverty (depending on which sample we consider). Under our lowest cost specification, the poverty rate is reduced to about 32 percent for the two eligibility groups shown in Table V.1. Under the intermediate specification, which costs less than $\$ 8,000$ per person annually, poverty declines to about 21 percent, while under the most expensive specification, poverty declines to between 8 and 9 percent. For reference purposes, the poverty rate around the time of onset for comparison cases used in the analysis in was about 8 percent (Schimmel and Stapleton 2010). Thus, under the most expensive scenario, poverty rates would be comparable to the rate for similar workers who did not experience a health-related work limitation. Note that the high level of poverty reduction under the most expensive scenario reflects our assumption about the effect of the EITC on earnings. The assumed mean increase in annual earnings of approximately $\$ 6,000$, coupled with the EITC and the ESA, greatly reduces the prevalence of poverty.

These are just simulations, of course, and they rely on assumptions about the effect of the work-support program on earnings. Unfortunately, the evidence base needed to predict impacts on household income is far from complete. The simulations illustrate the potential for a work-support program that is comparable in cost to a benefit preservation option to reduce financial hardship by rewarding, rather than penalizing, work. 
Page is intentionally left blank to allow for double side copying 


\section{CONCLUSIONS AND IMPLICATIONS FOR FUTURE RESEARCH AND POLICY}

The purpose of our analysis was to highlight work-support options as a practical alternative to benefit preservation, as proposals circulate that would delay or reduce access to retirement benefits for older workers. We examined a set of policies designed to reduce economic hardship among workers with health conditions limiting their ability to work, through a combination of earnings subsidies and employment allowances for those who do not enter SSDI. Our analysis shows that such a program need not cost more than options that would preserve the current benefits of such workers, and could cost less. Further, holding costs constant, such a program would have a more favorable effect on household income because it would encourage, rather than discourage, work.

Our analysis was constrained by three significant knowledge limitations. First, we could only use information available in a survey to determine eligibility for a program. Thus, we relied on a relatively simplistic model to predict which individuals would be targeted for a program designed to support those experiencing hardship after work limitation onset. This exercise involved making multiple assumptions-which definition of hardship to use, which characteristics to use to model the likelihood of hardship because of earnings loss associated with a work limitation under current law, and the minimum likelihood used as the eligibility cutoff.

Second, we did not have a basis for determining the share of those eligible who would actually enroll or what their characteristics would be. While our analysis was able to consider average costs across all individuals in the target population, actual total and average costs for a program such as the one we specified could be higher or lower depending on the type of workers who actually become eligible. We would expect take-up to be relatively low among those who do not experience substantial earnings declines or whose health conditions do not substantially limit their work and thus are not threatened with material hardship. If so, costs will be lower, and there will be fewer false positives among program participants. In addition, the impact on costs depends critically on 
the impact of entry into SSDI and Medicare; if the work-support program diverts many SSDI entrants, it could generate significant savings because it is less expensive.

Third, we do not know how the employment and earnings of eligible workers will change in response to introduction of a work-support option, relative to what they would be under a benefit preservation option. We made simple, and we think plausible, assumptions about the magnitude of earnings increases in response to the introduction of an EITC, but we do not know whether such assumptions are realistic for an older population with work limitations. Our findings are nonetheless instructive about the types of considerations that would be involved in designing a new program and the potential for cost savings and hardship reduction from such a program.

Program administration—particularly eligibility determination—is likely to be viewed as a major obstacle to implementation of a work-support program of this nature, reflecting the problematic experience of the SSDI eligibility determination process. That problem is an important reason why past proposals to expand the EITC for workers with disabilities have not been adopted. There are, however, important reasons why eligibility for this program could be much less difficult to determine.

The first is rapid expansion in the use of electronic medical records and the ongoing effort to implement the National Health Information Network (NHIN). SSA is already using electronic records obtained from cooperating local health information networks. This greatly simplifies disability determinations in multiple ways: the time required to obtain records is reduced from months to minutes, the information obtained is much more complete, and automated decision rules can be used to make determinations in many cases. In a world with an NHIN, a worker could submit a program application, including the requisite permission to access his or her electronic medical records, and medical eligibility requirements could be adjudicated in a matter of minutes. 
The efficiency of this system will depend, at least in part, on the specification of medical eligibility criteria; they would need to be objective, detailed, and clear.

To be sure, in some cases the medical record will not be definitive. In these cases, the program administrator might be tasked with conducting consultative examinations, following SSA's practice, but consideration should be given to making the applicant, rather than the government, responsible for providing valid medical evidence. The program administrator would also need to develop the capacity to audit medical evidence, to ensure that workers and their health care providers are not providing misinformation. Cases in which the medical cause of symptoms is difficult to establish will be a challenge for this system, as they are for SSA's disability determination process. Lower back pain is the most important example for the older worker population; depression might be as well.

A second reason that eligibility determinations would be less challenging than for SSDI is the less problematic nature of the eligibility criteria. For SSDI, the Social Security Act requires SSA to determine that the worker is unable to engage in SGA for medical reasons. The SGA criterion implies that an SSDI claimant can pursue a claim even after SSA has determined that the individual does not have a medical condition that satisfies the medical criteria that SSA has developed (that is, the Listing of Impairments). To adjudicate such cases, SSA must conduct Residual Functional Assessments (RFA) and compare the findings with the requirements of occupations that the worker would otherwise be qualified for. This step in the adjudication process is very difficult and error prone. The SGA criterion is likely an important reason why so many SSDI allowances are made only after an appeal of a denied claim to an administrative law judge (ALJ), SSA's Appeals Council, or the courts, in two ways: Claimants can appeal because of perceived errors in the RFA process or because they might be able to convince an ALJ or other adjudicator that they cannot engage in SGA for medical reasons, even though they fail to satisfy the evidentiary criteria developed by SSA. 
In contrast, the work-support program criteria would only require evidence of a specified medical condition; it would not require inability to engage in SGA. The program would also impose nonmedical eligibility criteria that are much easier to adjudicate. The first of these would be age. The second would be based on past earnings, perhaps similar to the earnings history requirements for SSDI. Age and past earnings both serve to exclude from eligibility those who have had only a weak attachment to the labor force. Other potential criteria include occupation as of a specified age (for example, age 50) and education. As evidenced by our model, marital status is also an important predictor of the likelihood of financial hardship following work limitation onset (other things constant, the odds that a married worker will experience hardship are estimated to be only one-third of the odds for an unmarried worker), but use of marital status as a criterion would, in effect, penalize marriage.

Administrative challenges also apply to many benefit preservation options that have been proposed in the context of retirement policy reforms. The NCFRR proposal addresses the consequences of the proposed FRA increase for those who experience health-related work limitations as they approach the current FRA by including (1) an exemption for those "unable to work after age 62"; (2) a provision that "gives retirees the choice of collecting half of their benefits early and the other half at a later age to minimize the impact of actuarial reductions and support phased retirement options"; and (3) a requirement that the SSA "design a way to provide for the early retirement needs of workers in physical jobs," to be in place before the FRA increases by more than its currently scheduled increase. ${ }^{27}$

The Government Accountability Office (2010) provides information on a broader range of policies that have been proposed to offset the consequences of retirement policy reforms for older

\footnotetext{
${ }^{27}$ Workers with low wages because of medical conditions would also benefit from a fourth provision, although it is not targeted specifically at them: a minimum SSR benefit, indexed to wage growth.
} 
workers with health-related work limitations (GAO 2010). The benefit preservation approaches include expansion of eligibility for SSDI benefits for those age 62 or over (the NCFRR proposal to exempt those unable to work after age 62 could be considered a variant); reduction in the lowest age at which low-income individuals and couples can receive Supplemental Security Income (SSI) on the basis of age, rather than disability, from 65 to 62; and an "Elastic" EEA—an EEA of 64 for those in the top half of the earnings distribution at age $55,{ }^{1} 62$ for those in the bottom quarter of the distribution, and an intermediate age for those in the second quarter (Zhivan et al. 2008).

Any benefit preservation option that narrowly targets those with health-related work limitations will face the same eligibility determination challenges as work-support programs. This is most evident for proposed expansions of SSDI. The Elastic EEA avoids use of medical criteria by using earnings at age 55 to determine eligibility, but as the authors of that proposal note, this criterion results in eligibility for many workers who do not have health-related work limitations, and ineligibility for many who do. The same criterion could be used for a work-support program. We suspect, however, that policymakers will insist on a program that is more carefully targeted at those with health-related work limitations.

As the debate over fiscal reforms proceeds, policymakers should give due consideration to work-support proposals for older workers with health-related work-limitations, as an alternative to benefit preservation proposals. Compared to benefit preservation proposals, work-support proposals are conceptually more consistent with current policy reform proposals that would delay or reduce access to retirement benefits for older workers. They are also more consistent with the direction of change in disability policy and are likely to be more efficient in reducing material hardship among older workers. 
Page is intentionally left blank to allow for double side copying 


\section{REFERENCES}

Benitez-Silva, Hugo, Moshe Buchinsky, and John Rust. "How Large are the Classification Errors in the Social Security Disability Award Process?” NBER Working Paper 10219. Cambridge, MA: National Bureau of Economic Research, January 2004.

Bipartisan Policy Center. "Reviving the Economy, Cutting Spending and Debt, and Creating a Simple Pro-Growth Tax System.” Washington, DC: BPC, November 2010.

Bound, John. "Self-Reported versus Objective Measures of Health in Retirement Models." Journal of Human Resources, vol. 26, no. 1, 1991, pp. 106-138.

Chen, Li-Wu, and Phani Tej Adidam. "Pent-Up Demand: Health Care Use of the Uninsured Near Elderly.” Ann Arbor, MI: Economic Research Initiative on the Uninsured, July 2004.

Coile, Courtney C. “Health Shocks and Couples' Labor Supply Decisions.” NBER Working Paper 10810. Cambridge, MA: National Bureau of Economic Research, September 2004.

Coile, Courtney C., and Kevin Milligan. "How Portfolios Evolve After Retirement: The Effect of Health Shocks" NBER Working Paper 12391. National Bureau of Economic Research, July 2006 .

Dahl, Molly, and Noah Meyerson. "Social Security Disability Insurance: Participation Trends and their Fiscal Implications.” Washington, DC: Congressional Budget Office, July 2010.

Employee Benefits Research Institute. "Fast Facts: Health Insurance Coverage by Age Group." Fast Facts from EBRI 135, Washington, DC: Employee Benefit Research Institute, September 2009.

Eissa, Nada, and Hilary Hoynes. "Behavioral Responses to Taxes: Lessons from the EITC and Labor Supply." NBER Working Paper 11729. Cambridge, MA: National Bureau of Economic Research, November 2005.

GAO. "Social Security Reform: Raising the Retirement Ages Would Have Implications for Older Workers and SSA Disability Rolls.” Washington, DC: GAO, November 2010.

Hacker, Jacob S., Gregory Huber, Philipp Rehm, Mark Schlesinger, and Rob Valletta. "Economic Security at Risk: Findings from the Economic Security Index." New York, NY: The Rockefeller Foundation, July 2010.

Johnson, Richard W., and Gordon B.T. Mermin. "Economic Hardship Before Qualifying for Social Security Retirement Benefits." 10th Annual Joint Conference of the Retirement Research Consortium, August 7-8, 2008.

Johnson, Richard W., Gordon B.T. Mermin, and Cori E. Uccello. "When the Nest Egg Cracks: Financial Consequences of Health Problems, Marital Status Changes, and Job Layoffs at Older Ages." Washington, DC: The Urban Institute, January 2006. 
Johnson, Richard W., Gordon B.T. Mermin, and Dan Murphy. "The Impact of Late-Career Health and Employment Shocks on Social Security and Other Wealth." Chestnut Hill, MA: Center for Retirement Research at Boston College, December 2007.

Kaiser Family Foundation. Focus on Health Reform: Summary of New Health Reform Law. Available at http://www.kff.org/healthreform/upload/finalhcr.pdf. Accessed March 26, $2010 \mathrm{a}$.

Kaiser Family Foundation. Survey of People Who Purchase Their Own Insurance. Available at http://www.kff.org/kaiserpolls/upload/8077-R.pdf. Accessed June 2010b.

McWilliams, J. Michael, Alan M. Zaslavsky, Ellen Meara, and John Z. Ayanian. "Impact of Medicare Coverage on Basic Clinical Services for Previously Uninsured Adults." The Journal of the American Medical Association, no. 290, 2003. pp. 757-764.

McWilliams, J. Michael, Ellen Meara, Alan M. Zaslavsky, John Z. Ayanian. "Use of Health Services by Previously Uninsured Medicare Beneficiaries." New England Journal of Medicine, no. 357, 2007a, pp. 143-53.

McWilliams, J. Michael, Ellen Meara, Alan M. Zaslavsky, John Z. Ayanian. "Health of Previously Uninsured Adults after Acquiring Medicare Coverage." The Journal of the American Medical Association, no. 298, 2007b, pp. 2886-94.

National Commission on Fiscal Responsibility and Reform. "The Moment of Truth." Washington, DC: NCFRR, December 2010.

Schimmel, Jody L. "The Effect of Health Insurance on the Health, Health Insurance, and Labor Market Outcomes of the Near-Elderly: Evidence from the Health and Retirement Study." Doctoral dissertation. Ann Arbor, MI: University of Michigan, 2005.

Schimmel, Jody, and David C. Stapleton. "How Well Are Older Workers Able to Offset Earnings Losses Following the Onset of New Health-Related Work Limitations?" Washington, DC: Mathematica Policy Research, October 2010.

SSA. "Annual Statistical Report on the Social Security Disability Insurance Program, 2009." Baltimore, MD: SSA, 2010a.

SSA. "Social Security Bulletin: Annual Statistical Supplement, 2009.” Baltimore, MD: SSA, 2010b.

Stapleton, David C. "Employment Support for the Transition to Retirement: Can a New Program Help Older Workers Continue to Work and Protect Those Who Cannot?” Washington, D.C.: AARP Policy Institute, April 2009.

Stapleton, David C., Ali Protik, and Christal Stone. "Review of International Evidence on the Cost of Disability." United Kingdom Department of Workforce and Pensions, Report No. 542, London: DWP, 2008.

Urban Institute and Brookings Institution Tax Policy Center. "Historical EITC Parameters" Available at http://www.taxpolicycenter.org/taxfacts/displayafact.cfm?Docid=36. Accessed December 14, 2010. 
U.S. Census Bureau. "Monthly Postcensal Civilian Noninstitutional Population, by Single Year of Age, Sex, Race, and Hispanic Origin." 2010. Available at [http://www.census.gov/popest/archives/1990s/nat_monthly_noninstitutional.html.] Accessed December 15, 2010.

Zhivan, Natalia, Steven A. Sass, Margarita Sapozhnikov, and Kelly Haverstick. "An 'Elastic' Earliest Eligibility Age for Social Security." Chestnut Hill, MA: Boston College Retirement Research Center, February 2008. 
Page is intentionally left blank to allow for double side copying 
APPENDIX 
Page is intentionally left blank to allow for double side copying 
Appendix Table 1. Size of Population Eligible for Program Under Various Assumptions, Using Sample of 51- to 52- Year- Olds in 1992 HRS

\begin{tabular}{|c|c|c|c|c|c|c|c|}
\hline & Wave 1 & Wave 2 & Wave 3 & Wave 4 & Wave 5 & Wave 6 & Wave 7 \\
\hline $\begin{array}{l}\text { Survey year } \\
\text { Age in wave }\end{array}$ & $\begin{array}{c}1992 \\
51-52\end{array}$ & $\begin{array}{l}1994 \\
53-54\end{array}$ & $\begin{array}{c}1996 \\
55-56\end{array}$ & $\begin{array}{l}1998 \\
57-58\end{array}$ & $\begin{array}{l}2000 \\
59-60\end{array}$ & $\begin{array}{l}2002 \\
61-62\end{array}$ & $\begin{array}{c}2004 \\
63-64\end{array}$ \\
\hline $\begin{array}{l}\text { Total population (thousands) } \\
\text { With work limitation (thousands) }\end{array}$ & $\begin{array}{r}4,808 \\
8134\end{array}$ & $\begin{array}{r}4,763 \\
955\end{array}$ & $\begin{array}{l}4,698 \\
1,121\end{array}$ & $\begin{array}{l}4,314 \\
1,014\end{array}$ & $\begin{array}{l}4,295 \\
1,091\end{array}$ & $\begin{array}{l}4,318 \\
1,080\end{array}$ & $\begin{array}{l}4,250 \\
1,148\end{array}$ \\
\hline $\begin{array}{l}\text { Eligibility in All Years of Reported W } \\
\text { Limitation (thousands) } \\
\text { With work limitation, no DI/SSI } \\
\text { Predicted probability of hardship }>0.2 \\
\text { Predicted probability of hardship }>0.3\end{array}$ & $\begin{array}{l}603 \\
309 \\
191\end{array}$ & $\begin{array}{l}736 \\
417 \\
248\end{array}$ & $\begin{array}{l}790 \\
437 \\
262\end{array}$ & $\begin{array}{l}695 \\
450 \\
341\end{array}$ & $\begin{array}{l}745 \\
524 \\
376\end{array}$ & $\begin{array}{l}740 \\
580 \\
454\end{array}$ & $\begin{array}{l}787 \\
617 \\
483\end{array}$ \\
\hline $\begin{array}{l}\text { Time- Limited Program; } 2 \text { Years Afte } \\
\text { Report at Age } 51 \text { and Older (thousan } \\
\text { With work limitation, no DI/ SSI } \\
\text { Predicted probability of hardship }>0.2 \\
\text { Predicted probability of hardship }>0.3\end{array}$ & $\begin{array}{l}603 \\
309 \\
191\end{array}$ & $\begin{array}{l}907 \\
476 \\
285\end{array}$ & $\begin{array}{l}635 \\
318 \\
176\end{array}$ & $\begin{array}{l}444 \\
230 \\
147\end{array}$ & $\begin{array}{l}318 \\
190 \\
134\end{array}$ & $\begin{array}{l}275 \\
199 \\
139\end{array}$ & $\begin{array}{l}293 \\
212 \\
148\end{array}$ \\
\hline $\begin{array}{l}\text { Time- Limited Program; } 2 \text { Years Afte } \\
\text { Report at Age } 55 \text { and Older (thousan } \\
\text { With work limitation, no DI/SSI } \\
\text { Predicted probability of hardship }>0.2 \\
\text { Predicted probability of hardship }>0.3\end{array}$ & $\begin{array}{l}-- \\
-- \\
--\end{array}$ & $\begin{array}{l}-- \\
-- \\
--\end{array}$ & $\begin{array}{r}1,384 \\
765 \\
458\end{array}$ & $\begin{array}{r}1,560 \\
874 \\
573\end{array}$ & $\begin{array}{l}700 \\
415 \\
311\end{array}$ & $\begin{array}{l}527 \\
394 \\
299\end{array}$ & $\begin{array}{l}469 \\
351 \\
266\end{array}$ \\
\hline
\end{tabular}

Source: Authors' calculations based on 1992-2008 HRS.

Note: $\quad$ The age group in each wave was determined based on birth year in the main HRS sampling year, ignoring issues of timing related to birth date relative to interview date. The population size in Wave 7 was imputed using the average growth rate of reported work limitation onset in Waves 1- 6 to account for error in Wave 7 survey skip logic whereby all individuals reporting a work limitation in Wave 6 were assumed to still have the limitation in Wave 7. 
Appendix Table 2. Total Annual Cost of Program Components Under Various Behavioral Assumptions

\begin{tabular}{|c|c|c|c|c|c|c|}
\hline & \multirow[b]{2}{*}{$\begin{array}{l}\text { Number } \\
\text { Eligible } \\
\text { (million) }\end{array}$} & \multirow[b]{2}{*}{$\begin{array}{l}\text { Health } \\
\text { Insurance } \\
\text { Subsidy } \\
\text { (\$ billions) }\end{array}$} & \multirow[b]{2}{*}{$\begin{array}{l}\text { Employment } \\
\text { Services } \\
\text { Allowance } \\
\text { (\$ billions) }\end{array}$} & \multicolumn{3}{|c|}{ EITC ( $\$$ billions) } \\
\hline & & & & $\begin{array}{c}\text { No } \\
\text { Change in } \\
\text { Work } \\
\text { Behavior }\end{array}$ & $\begin{array}{l}25 \text { Percent } \\
\text { Increase in } \\
\text { Earnings }\end{array}$ & $\begin{array}{l}50 \text { Percent } \\
\text { Increase in } \\
\text { Earnings }\end{array}$ \\
\hline \multicolumn{7}{|l|}{$\begin{array}{l}\text { Eligibility in All } \\
\text { Years of Reported } \\
\text { Work Limitation, } \\
\text { Age } 51-64\end{array}$} \\
\hline $\begin{array}{l}\text { Predicted probability } \\
\text { of hardship }>0.2\end{array}$ & 5.35 & 15.1 & 45.7 & 4.9 & 11.1 & 17.3 \\
\hline $\begin{array}{l}\text { Predicted probability } \\
\text { of hardship }>0.3\end{array}$ & 3.74 & 11.7 & 31.9 & 3.5 & 8.1 & 12.7 \\
\hline \multicolumn{7}{|l|}{$\begin{array}{l}\text { Eligibility in All } \\
\text { Years of Reported } \\
\text { Work Limitation, } \\
\text { Age 55- } 64\end{array}$} \\
\hline $\begin{array}{l}\text { Predicted probability } \\
\text { of hardship }>0.2\end{array}$ & 4.01 & 11.3 & 34.2 & 3.1 & 7.7 & 12.4 \\
\hline $\begin{array}{l}\text { Predicted probability } \\
\text { of hardship }>0.3\end{array}$ & 2.93 & 9.1 & 25.0 & 2.3 & 5.9 & 9.5 \\
\hline \multicolumn{7}{|l|}{$\begin{array}{l}\text { Eligibility in All } \\
\text { Years of Reported } \\
\text { Work Limitation, } \\
\text { Age } 60-64\end{array}$} \\
\hline $\begin{array}{l}\text { Predicted probability } \\
\text { of hardship }>0.2\end{array}$ & 2.09 & 5.9 & 17.8 & 1.3 & 3.8 & 6.3 \\
\hline $\begin{array}{l}\text { Predicted probability } \\
\text { of hardship }>0.3\end{array}$ & 1.61 & 5.0 & 13.7 & 1.0 & 3.0 & 5.0 \\
\hline \multicolumn{7}{|l|}{$\begin{array}{l}\text { Time- Limited } \\
\text { Program; } 2 \text { Years } \\
\text { After First Report, } \\
\text { Age } 51-64\end{array}$} \\
\hline $\begin{array}{l}\text { Predicted probability } \\
\text { of hardship }>0.2\end{array}$ & 3.26 & 8.7 & 27.8 & 4.3 & 7.5 & 10.7 \\
\hline $\begin{array}{l}\text { Predicted probability } \\
\text { of hardship }>0.3\end{array}$ & 2.04 & 6.2 & 17.4 & 2.9 & 5.0 & 7.1 \\
\hline \multicolumn{7}{|l|}{$\begin{array}{l}\text { Time- Limited } \\
\text { Program; } 2 \text { Years } \\
\text { After First Report, } \\
\text { Age } 55-64\end{array}$} \\
\hline $\begin{array}{l}\text { Predicted probability } \\
\text { of hardship }>0.2\end{array}$ & 2.80 & 7.5 & 23.9 & 3.0 & 5.8 & 8.7 \\
\hline $\begin{array}{l}\text { Predicted probability } \\
\text { of hardship }>0.3\end{array}$ & 1.91 & 5.7 & 16.3 & 2.2 & 4.2 & 6.2 \\
\hline
\end{tabular}

Source: Authors' calculations based on 1992-2008 HRS and assumptions about the cost of each program component. 
Appendix Table 3. Per Capita Cost of Program Components Under Various Assumptions

\begin{tabular}{|c|c|c|c|c|c|}
\hline & \multirow[b]{2}{*}{$\begin{array}{c}\text { Health } \\
\text { Insurance } \\
\text { Subsidy }(\$)\end{array}$} & \multirow[b]{2}{*}{$\begin{array}{l}\text { Employment } \\
\text { Services } \\
\text { Allowance (\$) }\end{array}$} & \multicolumn{3}{|c|}{ EITC (\$) } \\
\hline & & & $\begin{array}{l}\text { No Change } \\
\text { in Work } \\
\text { Behavior }\end{array}$ & $\begin{array}{l}25 \text { Percent } \\
\text { Increase in } \\
\text { Earnings }\end{array}$ & $\begin{array}{l}50 \text { Percent } \\
\text { Increase in } \\
\text { Earnings }\end{array}$ \\
\hline \multicolumn{6}{|c|}{$\begin{array}{l}\text { Eligibility in All Years of } \\
\text { Reported Work Limitation, } \\
\text { Age } 51-64\end{array}$} \\
\hline $\begin{array}{l}\text { Predicted probability of } \\
\text { hardship }>0.2\end{array}$ & 2,826 & 8,532 & 911 & 2,069 & 3,228 \\
\hline $\begin{array}{l}\text { Predicted probability of } \\
\text { hardship }>0.3\end{array}$ & 3,135 & 8,532 & 930 & 2,158 & 3,385 \\
\hline \multicolumn{6}{|c|}{$\begin{array}{l}\text { Eligibility in All Years of } \\
\text { Reported Work Limitation, } \\
\text { Age 55- } 64\end{array}$} \\
\hline $\begin{array}{l}\text { Predicted probability of } \\
\text { hardship }>0.2\end{array}$ & 2,821 & 8,532 & 764 & 1,929 & 3,094 \\
\hline $\begin{array}{l}\text { Predicted probability of } \\
\text { hardship }>0.3\end{array}$ & 3,117 & 8,532 & 786 & 2,013 & 3,240 \\
\hline \multicolumn{6}{|c|}{$\begin{array}{l}\text { Eligibility in All Years of } \\
\text { Reported Work Limitation, } \\
\text { Age } 60-64\end{array}$} \\
\hline $\begin{array}{l}\text { Predicted probability of } \\
\text { hardship }>0.2\end{array}$ & 2,837 & 8,532 & 619 & 1,816 & 3,013 \\
\hline $\begin{array}{l}\text { Predicted probability of } \\
\text { hardship }>0.3\end{array}$ & 3,106 & 8,532 & 611 & 1,867 & 3,124 \\
\hline \multicolumn{6}{|c|}{$\begin{array}{l}\text { Time- Limited Program; } 2 \\
\text { Years After First Report, } \\
\text { Age 51- } 64\end{array}$} \\
\hline $\begin{array}{l}\text { Predicted probability of } \\
\text { hardship }>0.2\end{array}$ & 2,675 & 8,532 & 1,330 & 2,306 & 3,282 \\
\hline $\begin{array}{l}\text { Predicted probability of } \\
\text { hardship }>0.3\end{array}$ & 3,038 & 8,532 & 1,412 & 2,434 & 3,456 \\
\hline \multicolumn{6}{|c|}{$\begin{array}{l}\text { Time- Limited Program; } 2 \\
\text { Years After First Report, } \\
\text { Age 55- } 64\end{array}$} \\
\hline $\begin{array}{l}\text { Predicted probability of } \\
\text { hardship }>0.2\end{array}$ & 2,667 & 8,532 & 1,069 & 2,086 & 3,103 \\
\hline $\begin{array}{l}\text { Predicted probability of } \\
\text { hardship }>0.3\end{array}$ & 2,988 & 8,532 & 1,145 & 2,189 & 3,234 \\
\hline
\end{tabular}

Source: Authors' calculations based on 1992-2008 HRS and assumptions about the cost of each program component. 